University for Business and Technology in Kosovo

UBT Knowledge Center

Oct 27th, 9:00 AM - 10:30 AM

\title{
The level of nutritional values on kids aged 4-6 years old fed in the preschools of Pollog region
}

\author{
Gafur Xhabiri \\ University for Business and Technology, gafurr.xhabiri@ubt-uni.net \\ Era Bruçi \\ University for Business and Technology \\ Sara Selimi \\ University for Business and Technology
}

Follow this and additional works at: https://knowledgecenter.ubt-uni.net/conference

Part of the Food Science Commons

\begin{abstract}
Recommended Citation
Xhabiri, Gafur; Bruçi, Era; and Selimi, Sara, "The level of nutritional values on kids aged 4-6 years old fed in the preschools of Pollog region" (2018). UBT International Conference. 194.

https://knowledgecenter.ubt-uni.net/conference/2018/all-events/194

This Event is brought to you for free and open access by the Publication and Journals at UBT Knowledge Center. It has been accepted for inclusion in UBT International Conference by an authorized administrator of UBT Knowledge Center. For more information, please contact knowledge.center@ubt-uni.net.
\end{abstract}




\title{
The level of nutritional values on kids aged 4-6 years old fed in the preschools of Pollog region
}

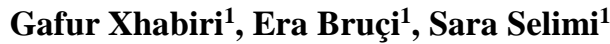 \\ ${ }^{1}$ Food Science and Biotechnology,UBT - Higher Education Institution, Lagjja \\ Kalabria, 10000 n.n., Prishtine, Kosovo \\ gafurr.xhabiri@ubt-uni.net
}

\begin{abstract}
The period of preschool kids is between 4-6 years old. Kids of this age need to eat healthy, they firstly need to satisfy energetic needs then the needs of macronutrients and micronutrients following the given recommendations, from which they will improve some eating habits too.

The study has been conducted on some public and private preschools on the Pollog region when kids aged 4-6 consume $75 \%$ of the daily food on which the study is based on.

From the conducted analysis it has been proven that that the energy intake of the mentioned age is matching the normative which is around $1200 \mathrm{kcal}$ for $75 \%$ of daily intake, the protein intake is matching the normative and also with an excellent ratio at $1: 1$ of proteins of plant and animal origin, the consumption of fats is matching the normative and there is a domination of unsaturated fats which fits in with the recommendations, the intake of carbohydrates is also matching the normative but with a higher intake of monosaccharides by $20 \%$. There has been noticed a deficit of magnesium and copper.
\end{abstract}

Keywords: preschool, Pollog, protein, monosaccharides, magnesium.

\section{INTRODUCTION}

Man has always changed nutrition habits, sometimes at best but sometimes at his own expense. These changes are influenced by social, geographical and economic factors as well as new knowledge about the use and toxicity of certain types of food or their components. Child nutrition is extremely important because inadequate food can spur improper consequences on the physical and psychic development of the child [1].The pre-school period is a time of intensive child growth and development. It is therefore important to know what, when, and how to offer the child a proper diet. Child nutrition in kindergartens is planned and controlled by the kindergarten and out-of-school institutions [2].Unfortunately, conditions, norms, or legal provisions are not fully implemented and fully respected in all kindergartens in the country.Consumption of a healthy diet is essential for children to ensure that they undergo normal growth and development and to prevent a variety of nutrition related health problems, such as anemia, growth retardation, malnutrition, compromised cognitive achievement, obesity, dental problems, and chronic diseases later in life [3-5]. The importance of having proper nutrition has in recent years been emphasized as a key factor in leading a healthy life and has contributed to the trend toward healthier diets [6].Insufficient nutrition information leads to many diet-related health problems, and it is necessary for people of all ages, especially children, to provide food education to mitigate these risks.In this respect, the most important mission of parents and particularly educators is to make the best use of the resources, teach students correct nutritional habits based on sound nutritional principles, correct wrong information and habits about nutrition and transform positive practices into a lifestyle [7].Based on scientific research, the study analyzes the proper nutrition of a preschool child, respectively by analyzing the day menus that have those nurseries analyzed possible deviations of current menus in terms of energy values and nutritional values. 


\section{MATERIALS AND METHODS}

The study included six gardens, and that three gardens from the city of Gostivar and from Tetovo, of which two in the city are public and a private one. The composition of food menus with nutrients is also different. Tables 1 and 2 provide menus for nursery $\mathrm{X}$ for a month where the first and third week have the same food composition and the second and fourth week have the same food composition.

Tabele 1. The composition of food in the nursery $\mathrm{X}$ for the first and third week

\begin{tabular}{|c|c|c|c|c|}
\hline Day & Breakfast & $\begin{array}{c}\text { Between } \\
\text { ration }\end{array}$ & Lunch & $\begin{array}{c}\text { Between } \\
\text { ration }\end{array}$ \\
\hline Monday & $\begin{array}{l}2 \text { pieces of bread } \\
\text { with marmalade } \\
\text { and a glass of milk }\end{array}$ & $\begin{array}{l}2 \text { seasonal } \\
\text { fruits }\end{array}$ & $\begin{array}{l}\text { Soup with chicken, } 1 \\
\text { plate pasta with cheese }\end{array}$ & 1 pudding \\
\hline Tuesday & $\begin{array}{l}1 \text { plate oat with } \\
\text { yogurt }\end{array}$ & $\begin{array}{l}2 \text { banana } \\
\text { creams }\end{array}$ & $\begin{array}{l}1 \text { plate of potatoes with } \\
\text { minced meat and salad, } \\
2 \text { pieces of bread }\end{array}$ & $\begin{array}{l}2 \text { seasonal } \\
\text { fruits }\end{array}$ \\
\hline Wednesday & $\begin{array}{l}2 \text { pieces bread, } \\
\text { cheese, eggs and } 1 \\
\text { glass of lemon tea } \\
\text { and } 2 \text { spoonful of } \\
\text { honey }\end{array}$ & $\begin{array}{l}2 \text { seasonal } \\
\text { fruits }\end{array}$ & $\begin{array}{l}1 \text { plate with minced } \\
\text { meat, } 1 \text { seasonal salad, } \\
2 \text { pieces of bread }\end{array}$ & $\begin{array}{l}1 \text { Croissant } \\
\text { or jogobella }\end{array}$ \\
\hline Thursday & $\begin{array}{l}3 \text { pieces of bread, } 2 \\
\text { zdenk, } 10 \quad \mathrm{~g} \\
\text { marmalade, } 1 \text { glass } \\
\text { of milk }\end{array}$ & $\begin{array}{l}100 \mathrm{~g} \text { biscuit } \\
\text { with } 150 \mathrm{ml} \\
\text { of milk }\end{array}$ & $\begin{array}{l}\text { Soup with vegetables, } \\
1 \text { plate mished patato } \\
\text { with minced meat and } \\
1 \text { seasonal salad }\end{array}$ & $\begin{array}{l}2 \text { seasonal } \\
\text { fruits }\end{array}$ \\
\hline Friday & $\begin{array}{l}2-3 \text { pieces of } \\
\text { bread, } 1 \text { chicken } \\
\text { pate with yogurt }\end{array}$ & 1 Jogobela & $\begin{array}{l}1 \text { plate beans, } 1 \text { plate } \\
\text { salad, } 2 \text { pieces of bread }\end{array}$ & $\begin{array}{l}1 \text { glass of } \\
\text { sulted } \\
\text { seasonal } \\
\text { fruit juice }\end{array}$ \\
\hline
\end{tabular}

Tabele 2. The composition of the food in the nursery $X$ for the second and the fourth week

\begin{tabular}{|c|c|c|c|c|}
\hline Day & Breakfast & $\begin{array}{l}\text { Between } \\
\text { ration }\end{array}$ & Lunch & $\begin{array}{c}\text { Between } \\
\text { ration }\end{array}$ \\
\hline Monday & $\begin{array}{l}2-3 \text { pieces of } \\
\text { bread } 10 \mathrm{~g} \text { butter } \\
\text { and } 20 \mathrm{~g} \text { cheese, } \\
\text { milk }\end{array}$ & $\begin{array}{l}1 \text { glass dense } \\
\text { fruit juice }\end{array}$ & $\begin{array}{l}\text { Soup with chicken } \\
\text { meat, } 1 \text { plate beans, } 1 \\
\text { plate salad shope, } 2- \\
3 \text { pieces of bread }\end{array}$ & 1 pudding \\
\hline Tuesday & $\begin{array}{l}1 \text { Plate polenta } \\
\text { with yogurt }\end{array}$ & \begin{tabular}{|ll}
2 & banana \\
creams &
\end{tabular} & $\begin{array}{l}1 \text { plate of potatoes } \\
\text { with minced meat and } \\
1 \text { plate village salad, } 2 \\
\text { pieces of bread }\end{array}$ & $\begin{array}{l}2 \text { seasonal } \\
\text { fruits }\end{array}$ \\
\hline Wednesday & $\begin{array}{l}2 \text { pieces of bread, } \\
25 \text { g cheese, } 2 \text { eggs } \\
\text { and lemon tea and } \\
2 \text { spoonful honey }\end{array}$ & $\begin{array}{ll}2 & \text { seasonal } \\
\text { fruits } & \end{array}$ & $\begin{array}{l}1 \text { plate goulash with } \\
\text { rice and other } \\
\text { vegetables, } 1 \text { mixed } \\
\text { salad, } 2 \text { pieces of } \\
\text { bread }\end{array}$ & $\begin{array}{l}\text { Croissant } \\
\text { or jogobela }\end{array}$ \\
\hline Thursday & $\begin{array}{l}2 \text { pieces of bread, } \\
2 \text { zdenk, } 10 \mathrm{~g} \\
\text { honey, } 1 \text { glass milk }\end{array}$ & $\begin{array}{lr}1 & \text { plate } \\
\text { biscuits } & \text { with } \\
\text { milk } & \\
\end{array}$ & $\begin{array}{l}\text { Soup with vegetables, } \\
\text { puree with minced } \\
\text { meat and seasonal } \\
\text { salad, } 2 \text { pieces of } \\
\text { bread }\end{array}$ & $\begin{array}{l}1 \text { seasonal } \\
\text { fruits }\end{array}$ \\
\hline Friday & $\begin{array}{l}2-3 \text { pieces of } \\
\text { bread, } 1 \text { chicken } \\
\text { pate with yogurt }\end{array}$ & 1 Jogobela & $\begin{array}{l}\text { Mixed soap, } 1 \text { fish } \\
\text { meat, } 1 \text { salad, } 2 \text { pieces } \\
\text { of bread }\end{array}$ & $\begin{array}{l}1 \text { pancake } \\
\text { with } \\
\text { eurokrem }\end{array}$ \\
\hline
\end{tabular}


Normally the composition of the tables is different when it comes to the season when the food is consumed. While the content of the tables is calculated the daily energy content, macronutrient substances such as protein, fat and carbohydrates and containing mineral substances. Calculation is done on the basis of nutrition charts, while the minimum, maximum, average, and deficit or surplus is calculated in comparison with the recommended norms. The calculation was done based on tables for nutritional values.

\section{RESULTS AND DISCUSSION}

Taking nutrients for children aged 4-6 years in nurseries depends on the time the children spend in nurseries. Our study included children who should consume $75 \%$ of food in the nursery and the rest remained at home. This means that this food is also basic food and that it needs to satisfy all the nutritional needs of macro-nutrition and micronutrients. Macro nutrients are nutrients that, by their cleavage, provide energy to the organism. The macronutrition group includes carbohydrates, dietary fiber, fatty acids, fatty acids, cholesterol, proteins and amino acids [8].In Graph 1, mean daily energy value is given during food consumption in the nursery $75 \%$, from which we can observe that the average energy calculated in the seasons of the energy intake is $1174.6 \mathrm{kcal}$, which is according to the recommended norm of $1160-1200 \mathrm{kcal}$.

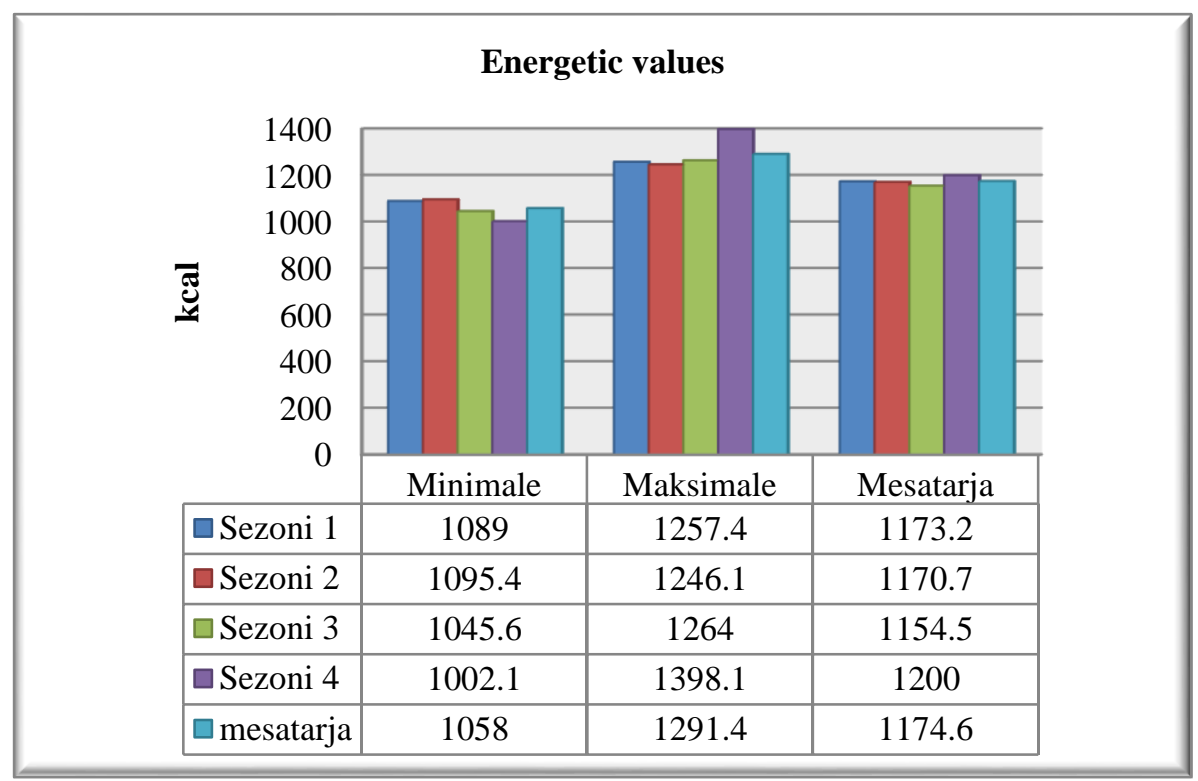

Graph 1. Daily average variation of energy values in the season

Table 3 shows the participation of macronutrients in daily diet of children 4-6 years in nurseries.From where we can notice that the presence of proteins is on average $31.77 \mathrm{~g}$, which corresponds to the recommended daily values of protein intake of $10-15 \%$, respectively the normative of 26.00-32.00 g.Fat participation also responds to the recommendations and every day a day consumes $41.02 \mathrm{~g}$ of fat in the nursery that is in compliance with the norm of 35.5 $44.40 \mathrm{~g}$, while the carbohydrate content is $174.4 \mathrm{~g}$, which is also in line with the recommendations and normative of $173.2-179.2 \mathrm{~g}$. 
Tabele 3.Participation of macronutrients energetic daily value

\begin{tabular}{|l|c|c|c|c|}
\hline & $\begin{array}{c}\text { Energy value } \\
(\mathbf{k c a l})\end{array}$ & Proteins $(\mathbf{g})$ & Fats $(\mathrm{g})$ & $\begin{array}{l}\text { Carbohydrates } \\
(\mathbf{g})\end{array}$ \\
\hline Minimum & 1058 & 26.76 & 32.61 & 159.78 \\
\hline Maximum & 1291.4 & 36.79 & 49.44 & 189.07 \\
\hline Average & 1174.6 & 31.77 & 41.02 & 174.4 \\
\hline Deficit & 0.00 & 0.00 & 0.00 & 0.00 \\
\hline Suficit & 0.00 & 0.00 & 0.00 & 0.00 \\
\hline Normative & $\mathbf{1 1 6 0 . 0 - 1 2 0 0 . 0}$ & $\mathbf{2 6 . 0 0 - 3 2 . 0 0}$ & $\mathbf{3 5 . 5 - 4 4 . 4 0}$ & $\mathbf{1 7 3 . 2 - 1 7 9 . 2}$ \\
\hline
\end{tabular}

Table 4 shows the participation of proteins of plant and animal origin. According to the recommendations, the consumption of proteins of plant and animal origin should be in the ratio of $1: 1$, meaning that, according to the participation obtained for proteins of plant origin of $15.70 \mathrm{~g}$ and proteins of animal origin of $16.07 \mathrm{~g}$, indicates an ideal ratio of them.

Table 4. Participation of proteins with plant and animal origin

\begin{tabular}{|l|c|c|c|c|}
\hline $\begin{array}{l}\text { Origin of } \\
\text { proteins }\end{array}$ & Normative .min-max & Gram & kcal & $\begin{array}{c}\text { \% generally of } \\
\text { energetic } \\
\text { values }\end{array}$ \\
\hline Plant & $\mathbf{1 3 . 0 0}-\mathbf{1 6 . 0 0}$ & 15.70 & 62.8 & 5.35 \\
\hline Animal & $\mathbf{1 3 . 0 0}-\mathbf{1 6 . 0 0}$ & 16.07 & 64.2 & 5.40 \\
\hline
\end{tabular}

Minerals are inorganic substances, present in all body tissues and fluids and their presence is necessary for the elements or minerals for their normal life processes [9, 10].

Calcium is a major nutrient in the human body. Food science is mainly focused on calcium in babies and toddlers [11].

Scientific evidence indicates that calcium plays a key role in bone and teeth health, to sum, that of collagen tissues [12].

Table 5 shows the participation of mineral substances in daily diet of children 4-6 years in nurseries. From where we can observe that calcium participation with $589.18 \mathrm{mg}$ is at normal limits although at a minimal value, iron participation is also within the normal range of 7.5 $\mathrm{mg}$, phosphorus is also at normal limits with $589.83 \mathrm{mg}$, as well as the participation of zinc is at the normal limit of $4.56 \mathrm{mg}$. Regarding the participation of magnesium it is within the normal limits of $76.17 \mathrm{mg}$ or with a deficit of $15.37 \%$, as well as the participation of copper is within the limits of $0.96 \mathrm{mg}$ or with a deficit of $28.7 \%$. on the other hand the sodium content is higher than normal with 676.60 or surplus of $11.3 \%$.

Tabela 5. Average participation of minerals substances

\begin{tabular}{|l|c|c|c|c|c|c|c|}
\hline $\begin{array}{l}\text { Minarals } \\
\text { mg / day }\end{array}$ & Na & Mg & Ca & Fe & Cu & P & Zn \\
\hline Average & 676.60 & 76.17 & 589.18 & 7.5 & 0.96 & 589.83 & 4.56 \\
\hline Deficit & 0.00 & 15.37 & 0.00 & 0.00 & 28.7 & 0.00 & 0.00 \\
\hline Suficit & 11.3 & 0.00 & 0.00 & 0.00 & 0.00 & 0.00 & 0.00 \\
\hline Normativ & $\mathbf{4 7 2 . 0 -}$ & $\mathbf{8 2 . 5}-$ & $\mathbf{5 4 0 . 0 -}$ & $\mathbf{6 . 7 5 -}$ & $\mathbf{1 . 1 2}-$ & $\mathbf{5 4 0 . 0 0}$ & $\mathbf{4 . 5 0}$ \\
min-max & $\mathbf{5 5 7 . 0}$ & $\mathbf{9 7 . 5}$ & $\mathbf{6 6 0 . 0}$ & $\mathbf{8 . 2 5}$ & $\mathbf{1 . 5 0}$ & $\mathbf{6 6 0 . 0 0}$ & $\mathbf{5 . 2 5}$ \\
\hline
\end{tabular}




\section{CONCLUSION}

From the results it can be concluded that children aged 4-6 years who consume nursery food receive optimal energy values with $1174.6 \mathrm{kcal}$. Taking macro-nutrients such as protein, fat, and carbohydrates is at the normal limits, and also the protein ratio of plant and animal origin is ideal with 1: 1. Mineral recovery is in most cases normal, but magnesium and copper deficits are $15.37 \%$ and $28.7 \%$, while sodium is in surplus of 11.3 .

\section{REFERENCES}

1. Prcel Mirjana, Prehrana djeteta, Školska knjiga, Zagreb, 1999.

2. Vučemilović Ljiljana \& Vujić Šisler Ljuba, Prehrambeni standard za planiranje prehrane djece u djecjem vrticu - jelovnici i normative, Hrvatska udruga medicinskih sestara, Zagreb, 2007.

3. Stang, J., Story, M. \& Calina, B., Nutrition education in Minnesota Public Schools: Perceptions and practices of teachers. Journal of Nutrition Education, 30, 396-404, (1998).

4. Ada A., Position of the American Dietetic Association: Nutrition guidance for healthy children ages 2 to 11 years, Journal of The American Dietetic Association, 108, 1038-1047, (2008).

5. Bralić, I. et al., Kako zdravo odrastati: Priručnik za roditelje o zdravlju i bolesti djeteta od rođenja do kraja puberteta Zagreb: Medicinska naklada, (2008).

6. Barzegari, A., Ebrahimi, M., Azizi, M. \& Ranjbar, K., A study of nutrition knowledge, attitudes and food habits of college students. World Applied Sciences Journal, 15 (7), 10121017, (2011).

7. Şanlıer, N., Ankara köylerindeki 0-6 yaş çocuklarının beslenme durumlarının incelenmesi üzerine bir araştırma. MEB Okul Öncesi Genel Müdürlüğü ve Gazi Üniversitesi Mesleki Eğitim Fakültesi İş Birliği İle, Ankara, (1999).

8. Bender Vranešić Darija, Krstev Sandra, Makronutrijenti i mikronutrijenti u prehrani čovjeka, MEDICUS, Vol. 17, No. 1, 19-25, (2008).

9. Hays VW., Swenson MJ., Minerals and Bones. In: Dukes' Physiology of Domestic Animals, Tenth Edition pp. 449-466, (1985).

10. Ozcan M., Mineral Contents of some Plants used as condiments in Turkey. Food Chemistry, 84: 437-440, (2003).

11. Beto A J., The Role of Calcium in Human Aging, Clinical Nutrition Researche, 4, 1-8. (2015).

12. Ross AC., Taylor CL., Yaktine AL., Del Valle HB., Dietary Reference Intakes for calcium and vitamin D. The National Academies Collection: Reports funded by National Institutes of Health. Washington (DC): National Academies Press (US); (2011). 